\title{
Extraction and Characterization of Starch Fractions of Five Phenotypes Pachyrhizus tuberosus (Lam.) Spreng
}

\author{
José Luis Ramírez Ascheri', Luz Haydee Bravo Zamudio², \\ Carlos Wanderlei Piler Carvalho', Arturo Melendez Arevalo ${ }^{3}$, \\ Lais Martins Fontoura ${ }^{3}$ \\ ${ }^{1}$ Rheology Laboratory, Embrapa Food Technology, Avenida das Américas, Rio de Janeiro, Brazil \\ ${ }^{2}$ Agronomy and Veterinary Medicine Faculty, Brazilian University, Campus Universitário Darcy Ribeiro, \\ Brasilia, Brazil \\ ${ }^{3}$ Graduate Program in Food Science and Technology, Federal Rural University of Rio de Janeiro, Seropédica, \\ Brazil \\ Email: jose.ascheri@embrapa.br
}

Received 26 August 2014; revised 16 September 2014; accepted 23 September 2014

Copyright (C) 2014 by authors and Scientific Research Publishing Inc.

This work is licensed under the Creative Commons Attribution International License (CC BY).

http://creativecommons.org/licenses/by/4.0/

(c) (i) Open Access

\section{Abstract}

Pachyrhizus tuberosus is a native plant of short life cycle found in South America riverside, which provides easy starch extraction from its tuberous roots. The aim of this study was to determine the physicochemical, rheological and functionality of the starch granules extracted from the roots of five phenotypes identified as V2, V3, V4, V6 and V7. Protein and ash content of all phenotypes were considerable high when compared to other root sources such as cassava varying from $4.35 \%$ to $7.43 \%$ and $1.58 \%$ to $2.49 \%$, respectively, whereas lipid content was lower, between 0.29 and $0.49 \%$. The starch granules were mostly circular and polygonal with varied sizes. The starch granules structural conformation showed cristallinity A type, normally for cereals. The maximum pasting viscosity at $95^{\circ} \mathrm{C}$ ranged from $1644 \mathrm{cP}$ (V7) to $2232 \mathrm{cP}$ (V2). The initial temperature of pasting formation occurred at $69.4^{\circ} \mathrm{C}$ for $\mathrm{V} 2,71.5^{\circ} \mathrm{C}$ for $\mathrm{V} 3,87.9^{\circ} \mathrm{C}$ for $\mathrm{V} 4,69.5^{\circ} \mathrm{C}$ for $\mathrm{V} 6$ and $71.5^{\circ} \mathrm{C}$ for V7. These values showed high variability within the phenotypes and generally high for roots and tubers starches. The maximum viscosity at $95^{\circ} \mathrm{C}$ for $\mathrm{V} 2, \mathrm{~V} 3, \mathrm{V4}, \mathrm{V} 6$ and $\mathrm{V} 7$ were 2232,2150 , 1995,2214 and $1644 \mathrm{cP}$, respectively. The viscosity curves showed low tendency to retrogradation. The thermal properties showed that the enthalpy of gelatinization varied from $8.91 \mathrm{~J} / \mathrm{g}$ (V3) to $11.78 \mathrm{~J} / \mathrm{g}(\mathrm{V} 2)$. The initial gelatinization temperature varied from $63.19^{\circ} \mathrm{C}(\mathrm{V} 6)$ to $65.14^{\circ} \mathrm{C}(\mathrm{V} 4)$. The swelling power at $90^{\circ} \mathrm{C}$ ranged from $14.7 \%$ to $20.1 \% \mathrm{p} / \mathrm{p}$ and solubility from $10.3 \%$ (V2) to 27.2\% (V7). It is concluded that Pachyrhizus tuberosus starch showed low retrogradation (1320 $1560 \mathrm{cP}$ ) comparable to non-common native waxy starches, a feature which indicates the capabil- 

ity of using this natural and easy extraction starch source as gelling agent in certain manufactured
food of undesirable retrogradation.

\section{Keywords}

\section{Pachyrhizus tuberosus, Physicochemical, Rheological, Starch Properties}

\section{Introduction}

Starch and its derivatives are used as ingredients and it is the main component in bakery products. It is also added in low quantities as additives to improve the sensory characteristics of a large number of manufactured foods. The products resulting from the hydrolysis of starches (glucose syrup or maltose, maltodextrins) and isomerization (iso-glucose or fructose) are used in the industries of candy, sweets, chocolates, cakes, pastries, as well as in the industries of jellies and desserts by its anti-crystallizing, sweetness or hygroscopicity (ability to hold water). In Brazil, about two-thirds of cassava starch is used by the food industry in its native form. It is noteworthy that the starches are used according to their characteristics or functional properties.

Pachyrhizus tuberosus is a leguminous, with a single tuberous root and stem herbaceous, robust and highly branched reaching up to six meters long. Its foliage is abundant dark green. The fruit is a pod linear-oblong 13 $19 \mathrm{~cm}$ long and $1.4-2.3 \mathrm{~cm}$ in width containing seeds inside. The main tuberous root is up to $30 \mathrm{~cm}$ long and 8 $25 \mathrm{~cm}$ in diameter. According to genotype may be so like globes, enlarged or irregular in cross-section, the pulp appears white, yellow, purple or white with rivets according to the phenotype (Figure 1).

Pachyrhizus tuberosus may be a promising starch resource for the farmer riverine Amazon region to achieve significant production of around 70 t/ha, short growing season in 4 - 6 months, plus considerable protein content of around $7 \%$. A similar tuberous root of same genus, Pachyrhizus ahipa, that provides considerable amount of easily extractable starch granules [1]-[4].

According to [5], Pachyrhizus ahipa is a legume native of South America of fast growth (harvest in five months resulting in 30 - 50 t/ha), considerable adaptability to climate changes and high starch content (45\% - 55\%

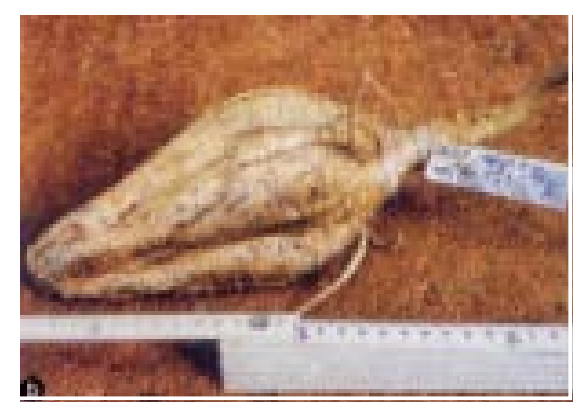

Yellow (V2)

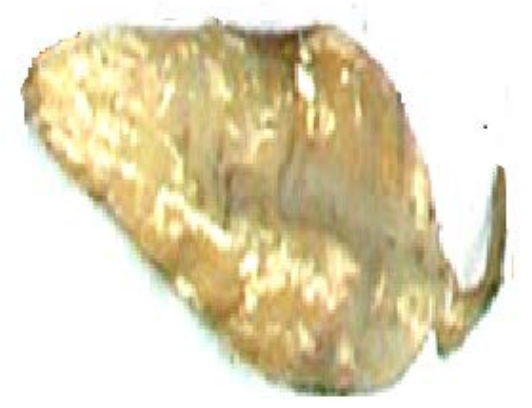

Yellow (V6)

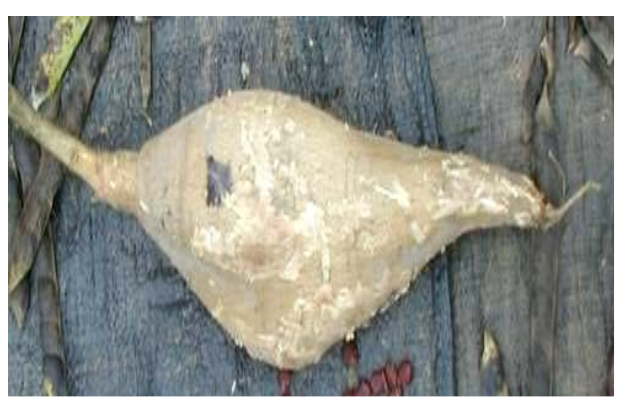

Cocotichuin purple (V4)

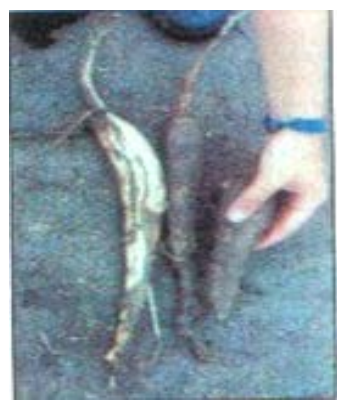

White (V3)

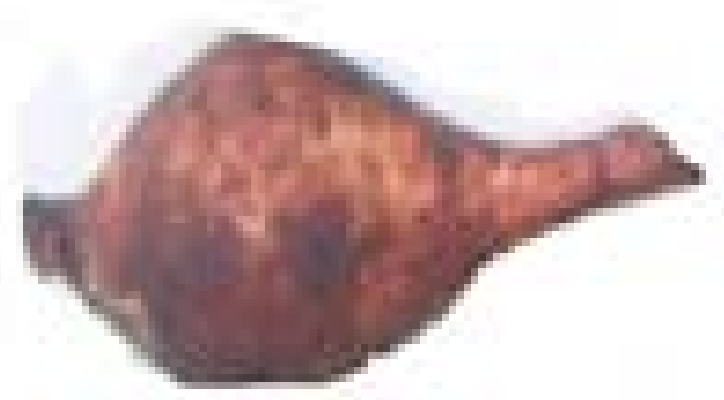

Yushpe (V7)

Figure 1. Digital images of five phenotypes variety of Pachyrhizus tuberosus originating from Peru. 
in dry basis) of very high amylopectin (95\% to 99\%). Although Pachyrhizus ahipa has been largely studied, there is no scientific study on the physicochemical properties of Pachyrhizus tuberosus starch.

On the other hand, starches for food industry uses can be exploited for certain functional properties, such us texture and viscosity. In this study, the starch from five Pachyrhizus tuberosus phenotypes roots was extracted and their morphology, thermal and rheological properties were analyzed, and Cassava starch was regarded as a standard sample.

\section{Materials and Methods}

\subsection{Plant Material}

Fresh tuberous roots of five phenotypes of Pachyrhizus tuberosus (Lam.) Spreng of different peel color were denominated brown (V2), white (V3), cocotichuin purpura (purple V4), yellow (V6) and yushpe (reddish peel V7). The roots were obtained from the Instituto Nacional de Investigaciones de la Amazonia Peruana (INIAP). (Figure 1) and processed to obtain starch granules. Moisture was determined by the method of the American Association of Cereal Chemists (2000) [6]. Ether extract and ash according to AOAC (2000) [7], protein by the method AACC (1995) [8]. The extraction of the starch was performed by successive washes followed by decanting, centrifugation and subsequent freeze drying, establishing a protocol for starch extraction in the laboratory (Figure 2). For comparison purposes, it was considered tapioca starch as reference in this study.

\subsection{Swelling Power and Solubility Percentage Determination}

The swelling power (SP) (Equation (1)) and solubility (\%S) (Equation (2)) were determined following the methodology described by Leach et al. [9].

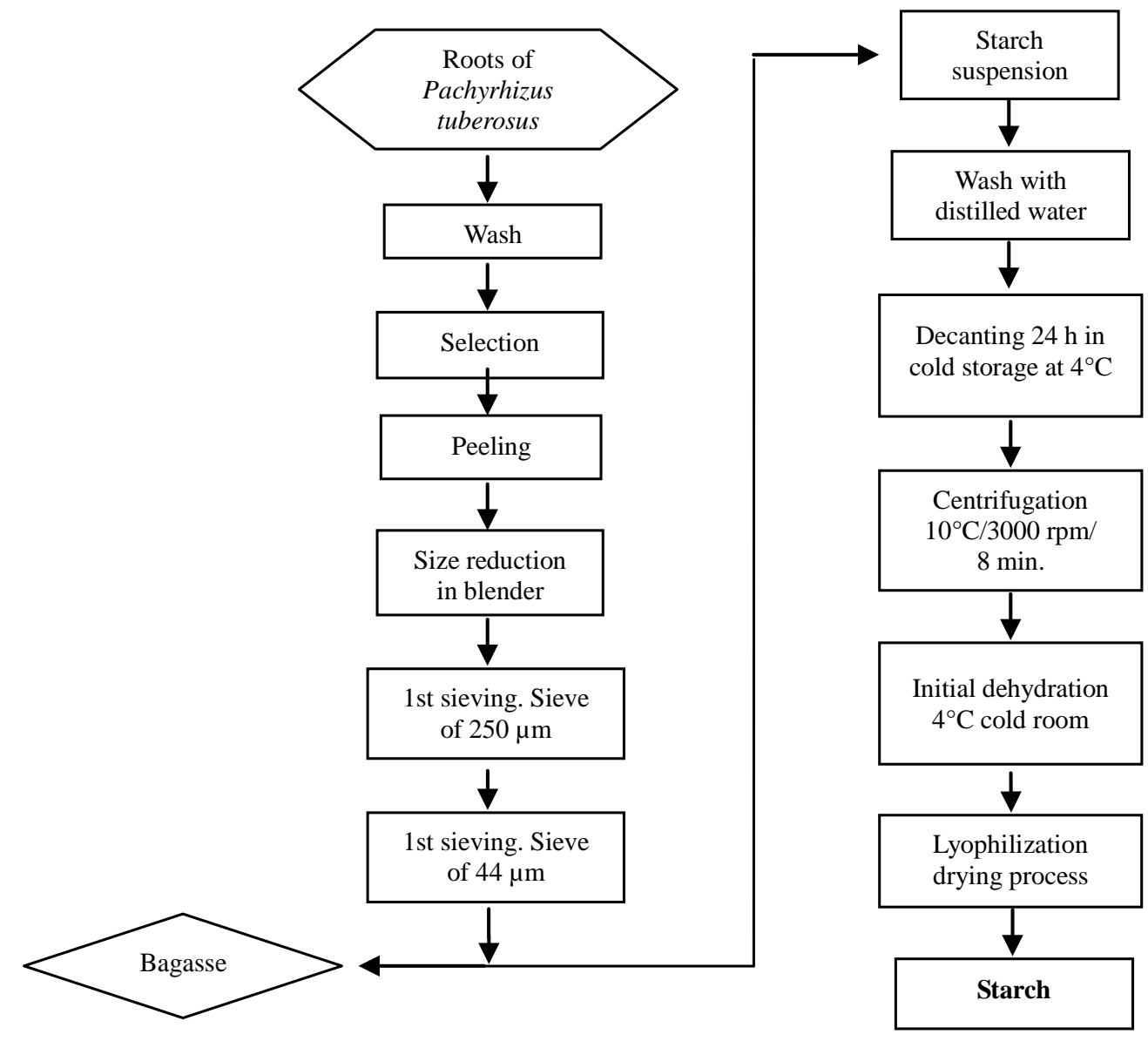

Figure 2. Flowchart of extracting starch in the roots of the phenotypes Pachyrhizus tuberosus. 


$$
\begin{gathered}
\mathrm{SP}=\frac{\text { sedimented sample }}{\text { sample weight }(\text { d.b. }) \cdot(100-\% \text { soluble })} \times 100 \\
\% S=\frac{\text { soluble } \text { starch }}{\text { sample }(\text { d.b. })} \times 400
\end{gathered}
$$

The wet mass of starch phenotypes were frozen in freezer at $-18^{\circ} \mathrm{C}$ and subjected to dehydration using a bench top lyophilizer (Thermo Savant, Holbrook, NY, USA) for a period of $16 \mathrm{~h}$. After this process, the lyophilized starch sample was comminuted with the aid of a blender for about one minute. The product obtained powder was stored in glass containers properly identified.

\subsection{Pasting Properties Determination}

Pasting properties were determined in a rapid visco analyzer (RVA 4, Newport Scientific, Warriewood, Australia) following the procedure described by [10] with modifications as follow. The suspension of starch in distil water $(9.0 \% \mathrm{w} / \mathrm{v})$ was equilibrated at $50^{\circ} \mathrm{C}$ for $1 \mathrm{~min}$ and then heated to $95^{\circ} \mathrm{C}$ at a rate of $5{ }^{\circ} \mathrm{C} / \mathrm{min}$, kept at this temperature for $4 \mathrm{~min}$. The suspension at $50^{\circ} \mathrm{C}$ was initially stirred at a speed of $960 \mathrm{rpm}$ for $10 \mathrm{~s}$ and then at $160 \mathrm{rpm}$ in order to stabilize the temperature and ensure uniform dispersion and wetting. It was heated to $95^{\circ} \mathrm{C}$ at a rate of $5^{\circ} \mathrm{C} / \mathrm{min}$, kept at this temperature for $4 \mathrm{~min}$ and then cooled to $50^{\circ} \mathrm{C}$ at a same rate adding 2 min until the end. In interpreting of the viscosity curve, the considered readings were: a) Initial paste viscosity at $25^{\circ} \mathrm{C}$, also called cold paste viscosity; b) maximum peak viscosity (in $\mathrm{cP}$ ) during the heating cycle; c) final viscosity read at the end of the curve; d) breakdown viscosity (difference between the maximum peak viscosity and the lowest viscosity after heating); e) set back viscosity (difference between the maximum viscosity during cooling and the lowest viscosity after the heating ramp).

\subsection{Thermal Properties Determination}

The thermal properties of the starches was determined using a differential scanning calorimeter (DSC) model Q200 (New Castle, Delaware, USA) with intracooler and thermal analysis software from the same manufacturer, according to the procedure of [10]. About $2 \mathrm{mg}$ of starch, on dry basis, were placed in hermetic aluminum capsules and is then added to three times its weight of deionized water and subsequently sealed. These capsules were kept at room temperature for $2 \mathrm{~h}$ to equilibrium before analysis. The capsules were then heated at a rate of $5^{\circ} \mathrm{C} / \mathrm{min}$ from $25^{\circ} \mathrm{C}$ to $125^{\circ} \mathrm{C}$ using an empty capsule as reference. The initial gelling temperature To, $T p$ and the peak $T f$ and the variation of the enthalpy $\Delta H$ from starches were determined using the software of the equipment, in triplicate.

\subsection{Amylose Content Determination}

The amylose content was determined using the colorimetric method as described by [11], with minor modifications. $100 \mathrm{mg}$ sample was transferred into a $100 \mathrm{~mL}$ volumetric flask, and added $1 \mathrm{~mL}$ of ethyl alcohol 96\% GL and $9 \mathrm{~mL}$ of $1 \mathrm{~N} \mathrm{NaOH}$ and placed in a water bath at $100^{\circ} \mathrm{C}$ for $10 \mathrm{~min}$, cooled for $30 \mathrm{~min}$ and the volume completed with distilled water. From each sample, an aliquot was removed, $5 \mathrm{~mL}$ and transferred to a $100 \mathrm{~mL}$ volumetric flask, which was added $1 \mathrm{~mL}$ of $1 \mathrm{~N}$ acetic acid and $2 \mathrm{~mL}$ of iodine solution (2\% w/v) prepared three hours before the analysis, being then completed the volume of each flask with distilled water. To the standard curve was used $40 \mathrm{mg}$ of standard amylose (Sigma) was subjected to the same procedure as in samples of flour and rice starch. Aliquots were collected 1, 2, 3, 4 and $5 \mathrm{~mL}$ of the volumetric flask was added and 0.2, 0.4, 0.6, 0.8 , and $1 \mathrm{~mL}$ of acetic acid and $0.4 ; 0.8,1.2,1.6$, and $2 \mathrm{~mL}$ of iodine, respectively, completing the volume to $100 \mathrm{~mL}$ with distilled water. The absorbance reading (Spectrophotometer Fento, model 600S, São Paulo, Brazil) was performed $30 \mathrm{~min}$ after addition of iodine solution at $610 \mathrm{~nm}$.

\subsection{Crystallinity Pattern Determination}

The crystallinity pattern of the starch granules was determined using an X-ray diffraction SPM XRD7 (Seifert, Germany), following the procedure described by [12]. The starch samples were conditioned in a desiccator at $75 \%$ $\mathrm{RH}$ under vacuum for $48 \mathrm{~h}$ and analyzed at $40 \mathrm{~kW}$ and $30 \mathrm{~mA}$ using CuK $\alpha$ radiation generated at a wavelength 
of $0.154 \mathrm{~nm}$. Subsequently the starch samples were scanned between the angles $2^{\circ}$ to $38^{\circ}(2 \theta)$ measured every $0.05^{\circ}(2 \theta)$ at detection time of $5 \mathrm{~s}$.

\subsection{Microstructure}

In order to visualize the external morphology of the starch granules, the optical microscope BX 60 (Olympus, Tokyo, Japan) with a 400× magnification lens was used. The starch granules were added into a solution of glycerol and water (1:1). For the same field, the visualized images were obtained under normal light and polarized light.

\subsection{Statistical Analysis}

Data are expressed as individual values and means. Analysis of variance was used to test for any significant difference among samples. Was used of Tukey (Statistica 7.0, Stattsoft, 2004, Tulsa, USA) Test for differences between samples at $\mathrm{p}<0.05$ significance. All tests were performed in triplicate.

\section{Results and Discussion}

The phenotypes of $P$. tuberosus have roots mono tuberous, elongated, rounded or irregular. The peel and pulp have different colors among different phenotypes: white (V3) has brown shell and white flesh and yellow (V2 and V6) have brown hulls and yellow squash; cocotichuin purple color (V4) with bark between the colors purple and brown and white flesh with purple and ribetes yushpe (V7) with intense yellow flesh and brown shell (Figure 1).

The proximal composition of the roots of five genotypes of Pachyrhizus tuberosus is presented in Table 1. The protein content, in dry basis, was ranged from $4.35 \%$ to $7.43 \%$, which is considered slightly superior when compared to other tuberous roots such us cassava, which presented around $4 \%$ content according to [13]. These results were close to that reported by [1] in two varieties of Pachyrhizus tuberosus, 5.2\% - 6.6\%, and lower than reported by the same author, $10.7 \%$ and $11.2 \%$ in protein. These results indicate a large genotype variation in protein content, which can be expected considering the distribution of this specie in the South America, also due to the environmental conditions.

The phenotypes V6 and V7 showed higher ash content than others. The lipid content was generally low similar to cassava root, $0.16 \%$ [13], however at least twice higher for $P$. tuberosus.

The extraction of starch $P$. tuberosus can be considered of easy extraction with rapid sedimentation. The average yield, in dry basis, was $13 \%$ (w/w), followed by the sample V4, V2, V3, V6 and V7 with $12.5 \%$, 12\%, $11.5 \%$ and $10 \%$ respectively of starch extracted.

The proximal composition (Table 2) showed values close to those of commercial starches with low impurity levels (Table 2), particularly to cassava starch. In general, the starch content of cassava roots is $20 \%$ - 30\% [14].

The micrographs of starch granules are shown in Figure 3, with and without polarized light. The granules have polygonal and circular shape, similar to the starches of Pachyrhizus ahipa, reported by [15]. In this group of starch, the hilum is centrally located and can be easily viewed. It can be observed different sizes, large size 21 $\mu \mathrm{m}$ (V2) and small $10 \mu \mathrm{m}(\mathrm{V} 7)$.

The amylose content gives very important information on the starch structure of polymer chain. The amylose

Table 1. Proximate composition (bs) roots of the variety of Pachyrhizus tuberosus.

\begin{tabular}{cccccc}
\hline Phenotypes & Protein (\%) & Ash (\%) & Ether extract (\%) & Carbohydrate (\%) & Moisture (\%) \\
\hline Yellow (V2) & $7.43^{\mathrm{a}}$ & $1.58^{\mathrm{b}}$ & $0.29^{\mathrm{b}}$ & $15.03^{\mathrm{b}}$ & $74.95^{\mathrm{c}}$ \\
White (V3) & $6.24^{\mathrm{ab}}$ & $1.68^{\mathrm{b}}$ & $0.29^{\mathrm{b}}$ & $3.58^{\mathrm{d}}$ & $87.45^{\mathrm{a}}$ \\
Cocotichuin purple (V4) & $5.42^{\mathrm{bc}}$ & $1.72^{\mathrm{b}}$ & $0.49^{\mathrm{a}}$ & $21.27^{\mathrm{a}}$ & $70.96^{\mathrm{d}}$ \\
Yellow (V6) & $7.08^{\mathrm{a}}$ & $2.25^{\mathrm{ab}}$ & $0.35^{\mathrm{ab}}$ & $14.75^{\mathrm{b}}$ & $75.14^{\mathrm{c}}$ \\
Yushpe (V7) & $4.35^{\mathrm{c}}$ & $2.49^{\mathrm{a}}$ & $0.43^{\mathrm{ab}}$ & $12.07^{\mathrm{c}}$ & $80.26^{\mathrm{b}}$ \\
\hline
\end{tabular}

${ }^{1}$ Factor, 6.25; ${ }^{2}$ Calculated by difference (100-protein-ether extract-ash-moisture); Data obtained after roots freeze-drying; Means with different letters in the same column differ significantly by Tukey test $(\mathrm{p}<0.05)$. 
Table 2. Proximate composition of starch extracted from roots of five phenotypes Pachyrhizus tuberosus.

\begin{tabular}{cccccc}
\hline Phenotypes & Protein $(\mathrm{g} / 100 \mathrm{~g})^{1}$ & Moisture (g/100g) & Ash (g/100g) & Ether extract (g/100g) & ${\text { Carbohydrate }(\mathrm{g} / 100 \mathrm{~g})^{2}}^{\text {Y }}$ \\
Yellow (V2) & $0.51^{\mathrm{c}}$ & $6.13^{\mathrm{b}}$ & $0.25^{\mathrm{a}}$ & $0.07^{\mathrm{a}}$ & $99.13^{\mathrm{bc}}$ \\
White (V3) & $0.44^{\mathrm{c}}$ & $11.31^{\mathrm{a}}$ & $0.19^{\mathrm{b}}$ & $0.09^{\mathrm{a}}$ & $99.28^{\mathrm{a}}$ \\
Cocotichuin purple (V4) & $0.92^{\mathrm{a}}$ & $5.61^{\mathrm{c}}$ & $0.25^{\mathrm{a}}$ & $0.21^{\mathrm{a}}$ & $98.59^{\mathrm{d}}$ \\
Yellow (V6) & $0.63^{\mathrm{b}}$ & $6.21^{\mathrm{b}}$ & $0.17^{\mathrm{b}}$ & $0.10^{\mathrm{a}}$ & $99.10^{\mathrm{c}}$ \\
Yushpe (V7) & $0.44^{\mathrm{c}}$ & $3.79^{\mathrm{d}}$ & $0.26^{\mathrm{a}}$ & $0.46^{\mathrm{a}}$ & $99.17^{\mathrm{b}}$ \\
\hline
\end{tabular}

${ }^{1}$ Factor, 6.25; ${ }^{2}$ Calculated by difference (100-protein-ether extract-ash-moisture). Data obtained after freeze-drying the roots; Means with different letters in the same column differ significantly by Tukey test $(\mathrm{p}<0.05)$.

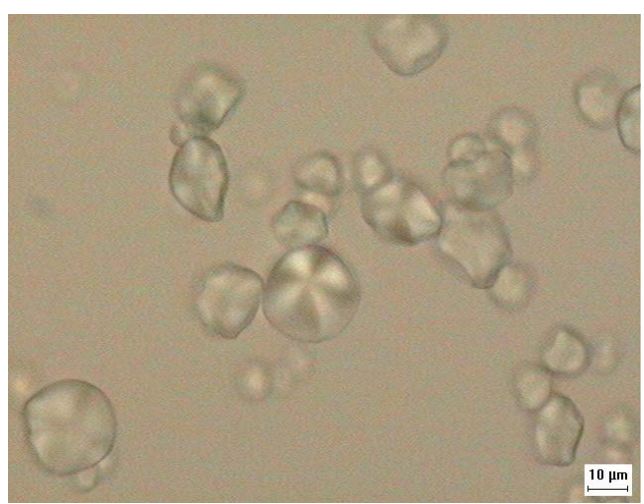

Yellow (V2). Normal light

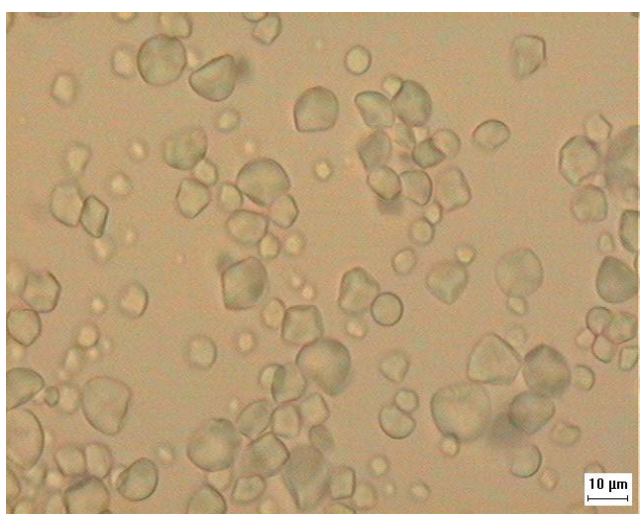

White (V3). Normal light

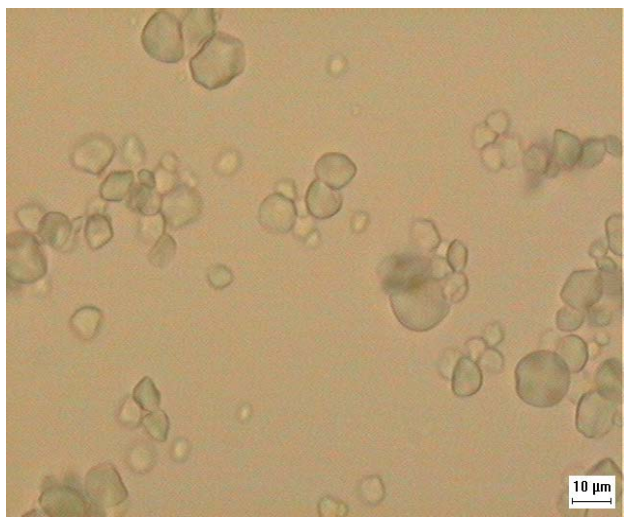

Cocotichuin purple (V4). Normal light

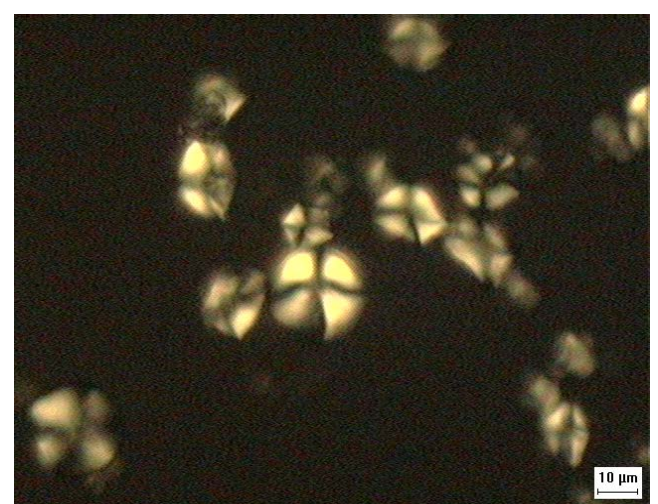

Yellow (V2). Polarized light

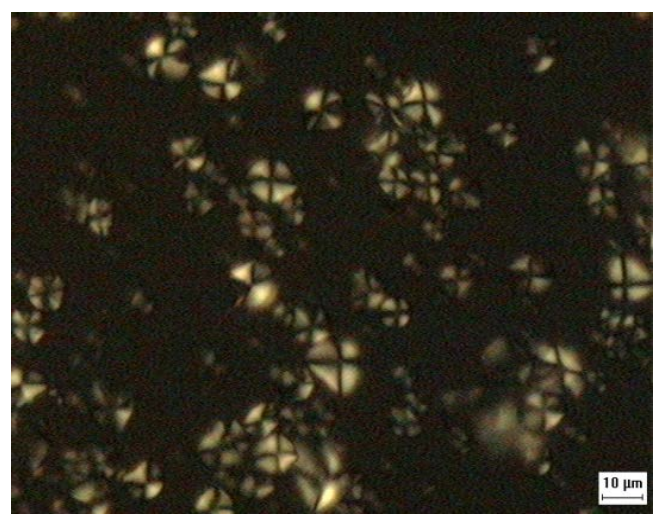

White (V3). Polarized light

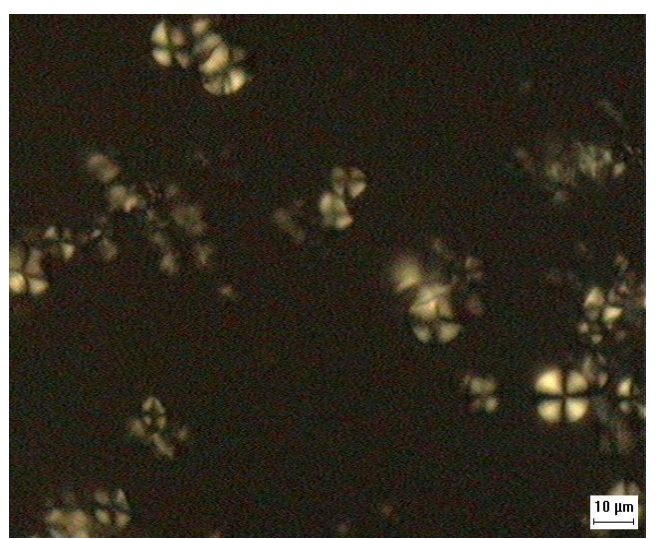

Cocotichuin purple (V4). Polarized light 

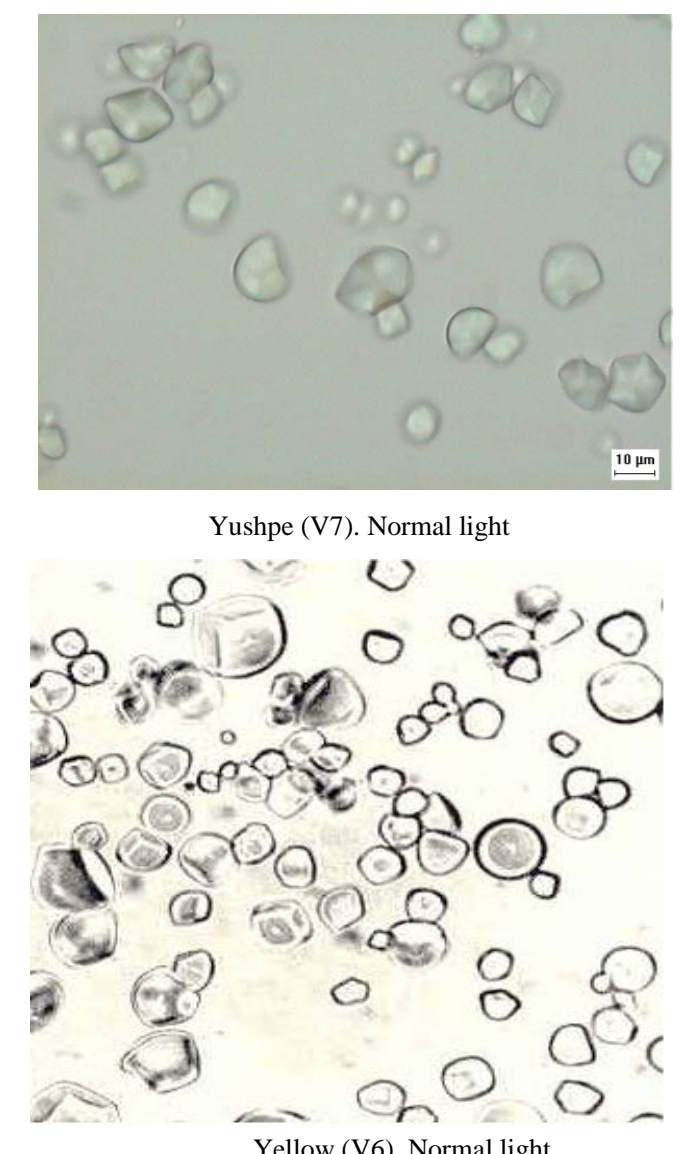

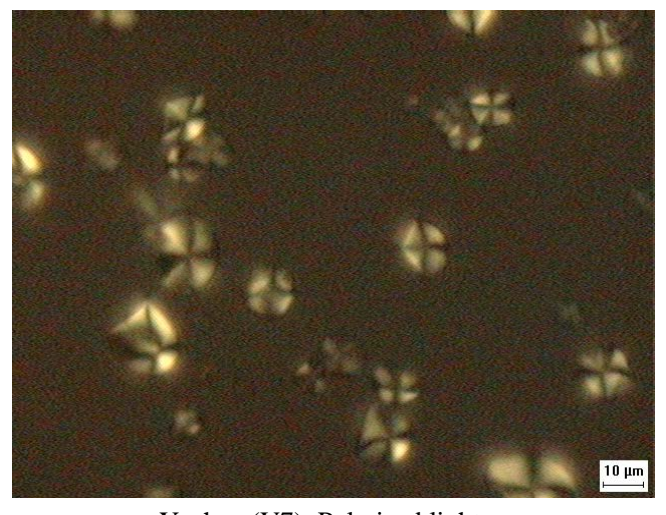

Yushpe (V7). Polarized light

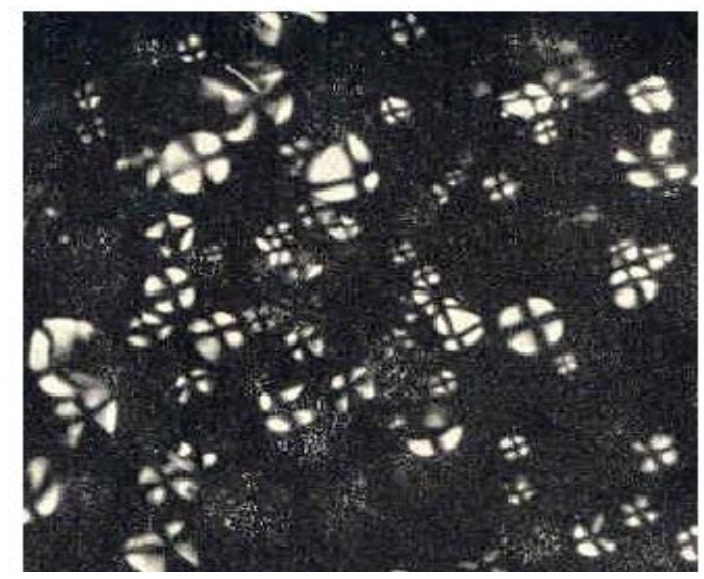

Yellow (V). Polarized light

Figure 3. Photomicrograph of starch granules from Pachyrhizus tuberosus phenotypes under normal and polarized light $(400 \times)$.

content of the studied starches was in the range between $9 \%$ - 15\% of amylose. The ratio of amylose/amylopectin may influence the functional properties, which is related to the degree of intermolecular association, shape, composition and distribution of crystalline regions in the starch granule, in turn the paste properties viscosity and gelling power, swelling power are affected.

According with several authors [9] [16]-[18] the swelling power (SP) is the physical property which determines the ability of hydration of the starch granules and for determining pulp viscosity is related to the viscosity maximum. The solubility of starches could be attributed in large extent to amylose leaching, which occurs during gelatinization. Starch shape and size, chains arrangement of amylose and amylopectin are determined by the crystalline structure of the starch granule, which control the capacity of retaining water in the string and to what extent it can resist to shearing [19]. The results of solubility of different phenotypes of Pachyrhizus tuberosus starch granules shown to be significantly different. Phenotypes V2 and V6 showed low value, whereas V7 and V4 were higher, 27.15\% (Table 3), which were close to arracacha starch (Arracacia xanthorriza), 27.07\%, determined by [20] and higher than normal corn, 25\% [21]. The SP of starch granules, Pachyrhizus tuberosus proved to be relatively lower than cassava, arracacha and also lower than starches from corn and wheat, 32.1\% 29.4\%, respectively, determined by [21] [22]. V7 showed similar SP value to Achira starch (Canna lily), 21.81\% [20].

The pasting curves are shown in Figure 4. The starch phenotype V2 showed the highest peak viscosity, followed by V6. These two samples were those that presented the highest amylose content. The phenotype V3 had the lowest amount of amylose (8.70\%), and presented the intermediate peak viscosity among the five phenotypes. The phenotype V7 presented the lowest peak viscosity value, but the highest value of swelling power (20.13\%). This could be related to associative internal forces (strong and uniform), including couplings of $+\mathrm{H}$ that would not have been broken. This can also be related to the low amylose content (9.12\%). Consequently, 
Table 3. Averages of amylose content, swelling power and percent solubility determinations of five roots Pachyrhizus tuberosus starch phenotypes.

\begin{tabular}{cccc}
\hline Phenotypes & Swelling Power & Solubility (\%) & Amylose (\%) \\
\hline Yellow (V2) & $17.51^{\mathrm{b}}$ & $10.28^{\mathrm{d}}$ & $13.50^{\mathrm{a}}$ \\
White (V3) & $14.79^{\mathrm{d}}$ & $15.10^{\mathrm{c}}$ & $8.70^{\mathrm{d}}$ \\
Cocotichuin purple (V4) & $19.71^{\mathrm{a}}$ & $15.56^{\mathrm{b}}$ & $9.20^{\mathrm{c}}$ \\
Yellow (V6) & $16.43^{\mathrm{c}}$ & $10.65^{\mathrm{d}}$ & $16.10^{\mathrm{a}}$ \\
Yushpe (V7) & $20.13^{\mathrm{a}}$ & $27.15^{\mathrm{a}}$ & $9.12^{\mathrm{c}}$ \\
\hline
\end{tabular}

Means with different letters in the same column differ significantly by Tukey test $(\mathrm{p}<0.05)$.

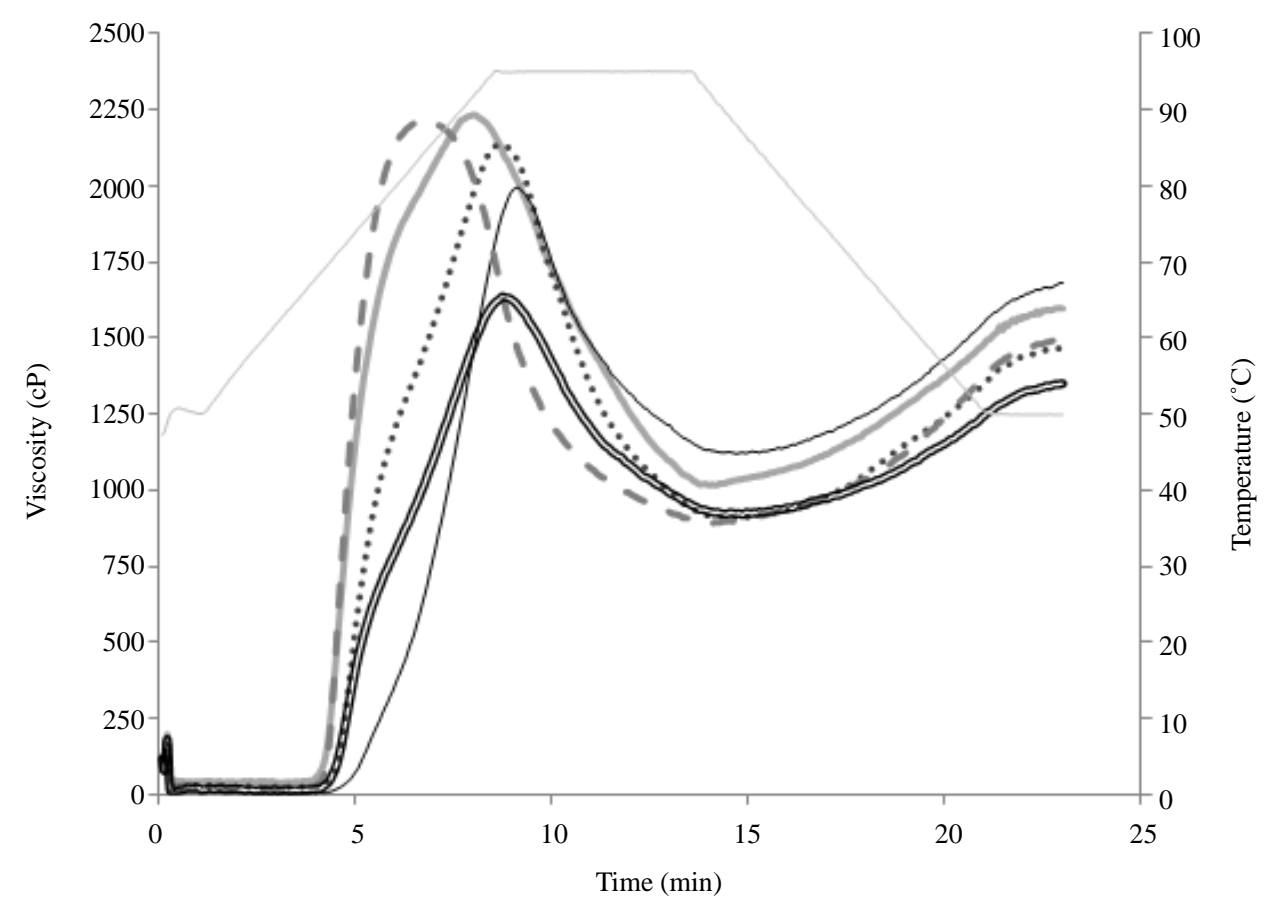

$\longrightarrow$ V2 $\cdots \cdots \cdot$ V3 $\longrightarrow$ V4 - V 6 V7 $\longrightarrow$ Temp. $\left({ }^{\circ} \mathrm{C}\right)$

Figure 4. Pasting viscosity profiles of five phenotypes of Pachyrhizus tuberosus (V2, V3, V4, V6 and V7).

high amylopectin content, during starch gelatinization, starch chains would be opened exposing great amount of $+\mathrm{H}$ linkages, which would be responsible for capturing greater amount of water. This condition may be interesting for certain uses when gelling effect is necessary. As V7 retrograde much less than other phenotypes, it could be better exploited in foods that require much greater stability with non-phase separation. The phenotypes V2 and V6, which presented amylose content about 15\%, had similar functional property close to cassava starch.

In general, Pachyrhizus tuberosus starch showed low tendency to retrogradation, which is related to low contents of amylose, useful characteristic for refrigerated products. The viscosity readings are shown in Table 4. All RVA curves showed a sharp increase and a peak, followed by a sharp drop in viscosity, which reflected the weakness of the granules subjected to heat in an aqueous medium. When compared to the paste viscosity of cereal starches, the setback viscosity (retrogradation) was not pronounced. The highest values of peak viscosity at $95^{\circ} \mathrm{C}$ were found to V2, V3 and V6, with similar values of ( $\left.<<0.05\right), 2232,2214$ and $2150 \mathrm{cP}$, respectively. The phenotypes V4 and V7 showed the lowest values, between 1995 and $1644 \mathrm{cP}$, respectively. These findings show a differentiation of the granular structure of starch phenotypes analyzed in this study. The retrogradation viscos- 
ity observed in Table 4, V2, V3 and V4, had similar values compared to cassava starch [5], whereas V7 showed the lowest value of $430 \mathrm{cP}$.

The thermal properties of the starches are presented in Table 5 . The gelatinization temperature range $\left(T_{0}-T_{c}\right)$, which defines the beginning and the end of the gelatinization representing the melt of the crystals of amylopectin was significantly different $(p<0.05)$. This was probably attributed to the structure arrangement of each starch phenotypes influenced by botanical aspects as well environmental conditions. The initial gelatinization temperature $\left(\mathrm{T}_{0}\right)$ was fairly similar with no significant difference between samples V3 and V4. When compared to the normal maize starch, which has around $28 \%$ of amylose content, $\mathrm{T}_{\mathrm{o}}$ was $64.92^{\circ} \mathrm{C}$ [23], which was similar to V3. The temperature of the conclusion of the amylopectin crystals occurred $\left(\mathrm{T}_{\mathrm{c}}\right)$ between $72.95^{\circ} \mathrm{C}$ and $75.99^{\circ} \mathrm{C}$, which was slight lower than maize starch [23]. The Pachyrhizus tuberosus gelatinization average enthalpy $(\Delta \mathrm{H})$ of all studied starches were around $11 \mathrm{~J} / \mathrm{g}$. The enthalpy of starch gelatinization is related to their structure and molecular arrangement, usually high entalphy values are correlated to high organization of the amylopectin crystals [24].

The molecular arrangement of starch granules was observed by X-ray diffraction, which is shown in Figure 5. All phenotypes showed the same X-ray A pattern crystal. It is known that relatively short outer chains of the amylopectin molecules (between 23 and 29 glucose units) favor the formation of crystalline polymorphs type A, found in cereal starches. In the diffractogram, it is also observed that the diffraction peaks corresponding to the Bragg angle $(2 \theta)$ are located at angles $15^{\circ}, 18^{\circ}$ and $23^{\circ}$, the same as the starch type A, also similar to cassava roots [25] [26]. According to Ascheri [27], who isolated starch from Adlay (Coix lacryma Jobi. L.) seeds also found crystallinity pattern of type A. X-ray diffraction of waxy maize starch [28] also presented pattern type A, which is thermodynamically more stable and its paste viscosity is thicker than B pattern, which indicates greater cohesiveness among their molecules.

\section{Conclusion}

The root of Pachyrhizus tuberosus presented low yield compared to cassava starch. The starch phenotype V7 has the lowest amylose content (9.12\%) among those studied phenotypes. All phenotypes presented A-type crystals revealed by $\mathrm{x}$-ray diffraction and relatively low temperature of gelatinization. Pasting properties showed

Table 4. Main parameters of pasting starch properties from five phenotypes.

\begin{tabular}{ccccccc}
\hline Phenotypes & $\begin{array}{c}\text { Peak Viscosity } \\
\text { at } 95^{\circ} \mathrm{C}(\mathrm{cP})\end{array}$ & $\begin{array}{c}\text { Breakdown } \\
\text { Viscosity (cP) }\end{array}$ & $\begin{array}{c}\text { Final Viscosity } \\
(\mathrm{cP})\end{array}$ & $\begin{array}{c}\text { Set Back Viscosity } \\
(\mathrm{cP})\end{array}$ & $\begin{array}{c}\text { Initial Paste } \\
\text { Viscosity }\left({ }^{\circ} \mathrm{C}\right)\end{array}$ & $\begin{array}{c}\text { Peak Time } \\
\text { Formation }\end{array}$ \\
\hline Yellow (V2) & $2232.0 \pm 4.9^{\mathrm{a}}$ & $1224.0 \pm 2.40^{\mathrm{b}}$ & $1597.2 \pm 2.30^{\mathrm{b}}$ & $582.0 \pm 0.20^{\mathrm{b}}$ & $69.4 \pm 0.20^{\mathrm{c}}$ & $8.0 \pm 0.0^{\mathrm{b}}$ \\
White (V3) & $2150.4 \pm 0.8^{\mathrm{a}}$ & $1248.0 \pm 18.9^{\mathrm{b}}$ & $1464.0 \pm 37.9^{\mathrm{c}}$ & $558.0 \pm 18.2^{\mathrm{b}}$ & $71.5 \pm 0.20^{\mathrm{b}}$ & $8.7 \pm 0.2^{\mathrm{b}}$ \\
Cocotichuin purple (V4) & $1995.6 \pm 1.5^{\mathrm{b}}$ & $876.0 \pm 5.00^{\mathrm{c}}$ & $1682.4 \pm 12.30^{\mathrm{a}}$ & $562.8 \pm 5.80^{\mathrm{b}}$ & $87.9 \pm 0.60^{\mathrm{a}}$ & $9.1 \pm 0.0^{\mathrm{a}}$ \\
Yellow (V6) & $2214.0 \pm 1.4^{\mathrm{a}}$ & $1323.6 \pm 1.10^{\mathrm{a}}$ & $1494.0 \pm 6.90^{\mathrm{c}}$ & $604.8 \pm 4.50^{\mathrm{a}}$ & $69.5 \pm 0.30^{\mathrm{c}}$ & $6.9 \pm 0.3_{\mathrm{c}}$ \\
Yushpe (V7) & $1644.0 \pm 5.1^{\mathrm{c}}$ & $720.0 \pm 1.80^{\mathrm{d}}$ & $1351.2 \pm 4.20^{\mathrm{d}}$ & $430.8 \pm 0.80^{\mathrm{c}}$ & $71.5 \pm 0.30^{\mathrm{b}}$ & $8.8 \pm 0.1^{\mathrm{b}}$ \\
\hline
\end{tabular}

Means with different letters in the same column differ significantly by Tukey test $(\mathrm{p}<0.05)$.

Table 5. Thermal properties of Pachyrhizus tuberosus starches.

\begin{tabular}{ccccc}
\hline Phenotypes & $\mathrm{T}_{\mathrm{o}}\left({ }^{\circ} \mathrm{C}\right)$ & $\mathrm{T}_{\mathrm{c}}\left({ }^{\circ} \mathrm{C}\right)$ & $\mathrm{T}_{\mathrm{o}}-\mathrm{T}_{\mathrm{c}}\left({ }^{\circ} \mathrm{C}\right)$ & $\Delta \mathrm{H}(\mathrm{J} / \mathrm{g})$ \\
\hline Yellow (V2) & $62.6^{\mathrm{d}}$ & $73.4^{\mathrm{c}}$ & $10.75^{\mathrm{b}}$ & $11.60^{\mathrm{a}}$ \\
White (V3) & $64.70^{\mathrm{a}}$ & $72.6^{\mathrm{d}}$ & $8.40^{\mathrm{c}}$ & $8.91^{\mathrm{d}}$ \\
Cocotichuin purple (V4) & $65.06^{\mathrm{a}}$ & $76.0^{\mathrm{a}}$ & $10.90^{\mathrm{b}}$ & $10.46^{\mathrm{c}}$ \\
Yellow (V6) & $63.20^{\mathrm{c}}$ & $75.1^{\mathrm{b}}$ & $11.60^{\mathrm{a}}$ & $11.21^{\mathrm{b}}$ \\
Yushpe (V7) & $64.10^{\mathrm{b}}$ & $73.1^{\mathrm{cd}}$ & $8.80^{\mathrm{c}}$ & $11.24^{\mathrm{b}}$ \\
\hline
\end{tabular}

$\mathrm{T}_{\mathrm{o}}=$ initial temperature; $\mathrm{T}_{\mathrm{c}}=$ temperature of completion of thermal event; $\mathrm{DH}=$ enthalpy change. Means with different letters in the same column differ significantly by Tukey test $(\mathrm{p}<0.05)$. 


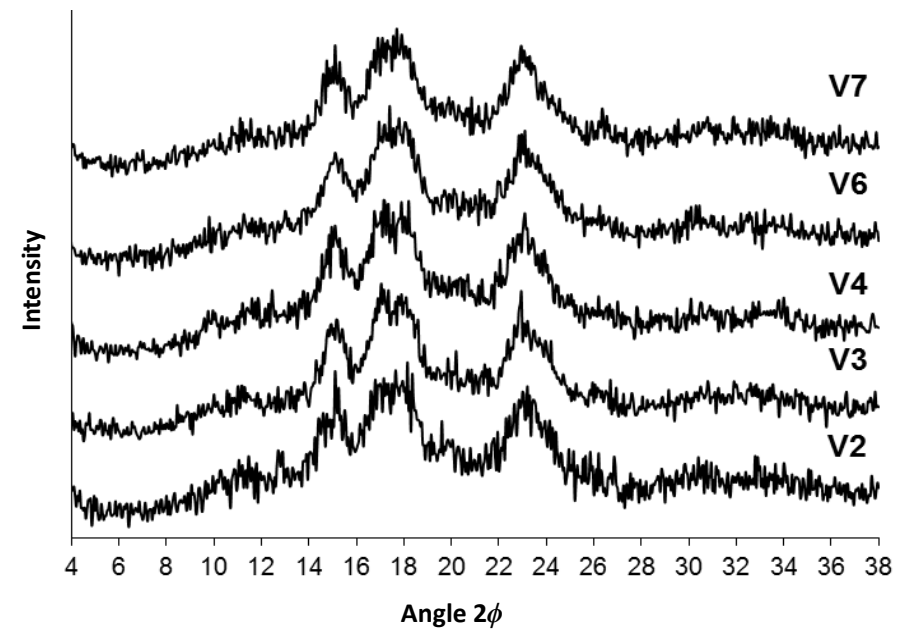

Figure 5. Diffractograms of starch from five phenotypes of Pachyrhizus tuberosus (V2, V3, V4, V6 and V7).

low retrogradation viscosity profile similar to waxy starches and cassava roots as well as high swelling power. These properties are interesting functionality for food manufacturing that requires the use of cold temperature for storing. Pachyrhizus tuberosus starches would be considered as a replacer in applications where cassava starch is used.

\section{Acknowledgements}

The authors thank Dr. Mejia Kember and Octavio Delgado Vásquez, who kindly provided the raw materials and also to CNPq for the scholarships granted to José Ascheri and Carlos Carvalho.

\section{References}

[1] Sørensen, M., Grüneberg, W.J. and Ørting, B. (1997) Ahipa Pachyrhizus Ahipa (Wedd.) Parodi. In: Hermann, M. and Heller, J., Eds., Andean Roots and Tubers: Ahipa, Arracacha, Maca and Yacon. Promoting the Conservation and Use of Underutilized and Neglected Crops 21, Institute of Plant Genetics and Crop Plant Research, Gatersleben/International Plant Genetic Resources Institute, Rome, 13-73.

[2] Bergthaller, W., Kjersting, H.J., Velasco, L. and Grüneberg, W.J. (2001) Andean Yam Bean (Pachyrhizus ahipa) Tubers as a New Source of a Legume Starch. Proceedings of the 4th European Conference on Grain Legumes, Cracow, 8-12 July 2001, European Association for Grain Legume Research (AEP), Paris, 392-393.

[3] Tapia, C. and Sørensen, M. (2003) Morphological Characterization of the Genetic Variation Existing in a Neotropical Collection of Yam Bean, Pachyrhizus tuberosus (Lam.) Spreng. Genetic Resources and Crop Evolution, 50, 681-692. http://dx.doi.org/10.1023/A:1025028617948

[4] Bermudez, J.J.H. (1997) Valorización de los Amiláceos no-cereales cultivados en los Países Andinos: Estudio de las Propiedades Fisicoquímicas y Funcionales de sus Almidones y de la Resistencia a Diferentes Tratamientos Estresantes. Thesis, Universidad de Bogotá, Colombia, 1-150.

[5] Leonel, M. and Cereda, M.P. (2002) Caracterização físico-química de algumas tuberosas amiláceas. Ciência e Tecnologia de Alimentos, 22, 65-69. http://dx.doi.org/10.1590/S0101-20612002000100012

[6] American Association of Cereal Chemists-AACC (2000) Approved Methods of the AACC. 10th Edition, Association of Official Analytical Chemists-AOAC, Saint Paul.

[7] Association of Official Analytical Chemists (2000) Official Methods of Analysis. 13th Edition, Association of Official Analytical Chemists, Washington DC.

[8] American Association of Cereal Chemists (1995) Approved Methods of the American Association of Cereal Chemists. 9th Edition, AACC, Saint Paul.

[9] Leach, H.W., McCowen, L.D. and Schoch, T.J. (1959) Structure of the Starch Granule. I. Swelling and Solubility Patterns of Various Starches. Cereal Chemistry, 36, 534-544.

[10] Franco, C.M.L., Wong, K.S., Yoo, S.H. and Jane, J.L. (2002) Structural and Functional Characteristics of Selected Soft 
Wheat Starches. Cereal Chemistry, 79, 243-248. http://dx.doi.org/10.1094/CCHEM.2002.79.2.243

[11] da Rosa Zavareze, E., El Halal, S.L.M., Pereira, J.M., Radünz, A.L., Elias, M.C. and Dias, A.R.G. (2009) Caracterização química e rendimento de extração de amido de arroz com diferentes teores de amilose. Brazilian Journal of Food Technology. II SSA, 24-30. http://bjft.ital.sp.gov.br/artigos/especiais/especial_2009/v11_edesp_06.pdf

[12] Carvalho, C.W.P. and Mitchell, J.R. (2001) Effect of Sucrose on Starch Conversion and Glass Transition of Nonexpanded Maize and Wheat Extrudates. Cereal Chemistry, St. Paul, 78, 342-348.

[13] Leonel, M., Cereda, M. and Jackey, S. (1998) Processamento industrial de fécula de mandioca e batata doce-um estudo de caso. Ciência e Tecnologia de Alimentos, Campinas, 18, 343-345.

[14] Leonel, M. and Cereda, M.P. (2000) Extração da fécula retida no resíduo fibroso do processo de produção de fécula de mandioca. Ciência e Tecnologia de Alimentos, Campinas, 20, 122-127.

[15] Cereda, M.P. and Vilpoux, O. (2003) Tecnologia, uso e potencialidades de tuberosas amiláceas latinoamericanas. Série: Culturas de Tuberosas Amiláceas Latinoamericanas, Vol. 3, Fundação Cargill, São Paulo.

[16] Nunes, L.B., de Jesus dos Santos, W. and Cruz, R.S. (2009) Rendimento de extração e caracterização química e funcional de féculas de mandioca da região do semi-árido baiano. Alimentos e Nutrição Araraquara, Araraquara, 20, 129-134.

[17] López, O.V., Viña, S.Z., Pachas, A., Sisterna, M.N., Rohatsch, P.H., Mugridge, A., Fassola, H.E. and García, M.A. (2010) Composition and Food Properties of Pachyrhizus ahipa Roots and Starch. International Journal of Food Science \& Technology, 45, 223-233. http://dx.doi.org/10.1111/j.1365-2621.2009.02125.x

[18] Singh, N., Sandhu, K.S. and Kaur, M. (2005) Physicochemical Properties Including Granular Morphology, Amylose Content, Swelling and Solubility, Thermal and Pasting Properties of Starches from Normal, Waxy, High Amylose and Sugary Corn. Progress in Food Biopolymer Research, 1, 44-54.

[19] Ciacco, F. and Cruz, R. (1982) Fabricação de amido e sua utilização. Série Tecnologia Agroindustrial, No. 7. Secretaria de Indústria e Comércio, Ciência e Tecnologia, São Paulo, 1-152.

[20] Peroni, F.H.G., Rocha, T.S. and Franco, C.M.L. (2006) Some Structural and Physicochemical Characteristics of Tuber and Root Starches. Food Science and Technology International, 12, 505-513. http://dx.doi.org/10.1177/1082013206073045

[21] Cereda, M.P., Franco, C.M.L., Daiuto, E.R., Demiate, I.M., Carvalho, L.J.C.B., Leonel, M., Vilpoux, O.F. and Sarmento, S.B.S. (2001) Propriedades gerais do Amido. Série: Culturas de Tuberosas Amiláceas latino-americanas, Vol. 1, Fundação Cargill, Campinas.

[22] Ascheri, J.L.R. (1996) Characterization of Job’s Tears Starch. I. Extraction and Physical Properties of the Starch Granules. Alimentaria, 96, 97-100.

[23] Weber, F.H., Collares-Queiroz, F.P. and Chang, Y.K. (2009) Caracterização físico-química, reológica, morfológica e térmica dos amidos de milho normal, ceroso e com alto teor de amilose. Ciência e Tecnologia de Alimentos, Campinas, 29, 748-753.

[24] Tester, R.F. and Morrison, W.R. (1990) Swelling and Gelatinization of Cereal Starches. I. Effects of Amylopectin, Amylose and Lipids. American Association of Cereal Chemists, 67, 551-557. http://www.aaccnet.org/publications/cc/backissues/1990/documents/67 551.pdf

[25] Ascheri, J.L.R. (1987) Extração e caracterização do amido de Adlay (Coix lacryma Jobi L.). Master Thesis in Food Science and Technology, Food Engineering Faculty, Universidade Estadual de Campinas-UNICAMP, Campinas, $1-130$.

[26] Felippe, Ó.R. and Andrade, C.T. (2012) Ternary Nanocomposites of Thermoplastic Starch and Maleated Polybutadiene. Quimica Nova, São Paulo, 35, 1146-1150.

[27] Ascheri, J.L.R. (1996) Characterization of Job’s Tears Starch. II. Pasting Characteristics. Alimentaria, 96, $101-104$.

[28] Teixeira, M.A.V., Ciacco, C.F., Tavares, D.Q. and Bonezzi, A.N. (1998) Ocorrência e caracterização do amido resistente em amidos de milho e de banana. Ciência e Tecnologia de Alimentos, Campinas, 18, 246. 
Scientific Research Publishing (SCIRP) is one of the largest Open Access journal publishers. It is currently publishing more than 200 open access, online, peer-reviewed journals covering a wide range of academic disciplines. SCIRP serves the worldwide academic communities and contributes to the progress and application of science with its publication.

Other selected journals from SCIRP are listed as below. Submit your manuscript to us via either submit@scirp.org or Online Submission Portal.
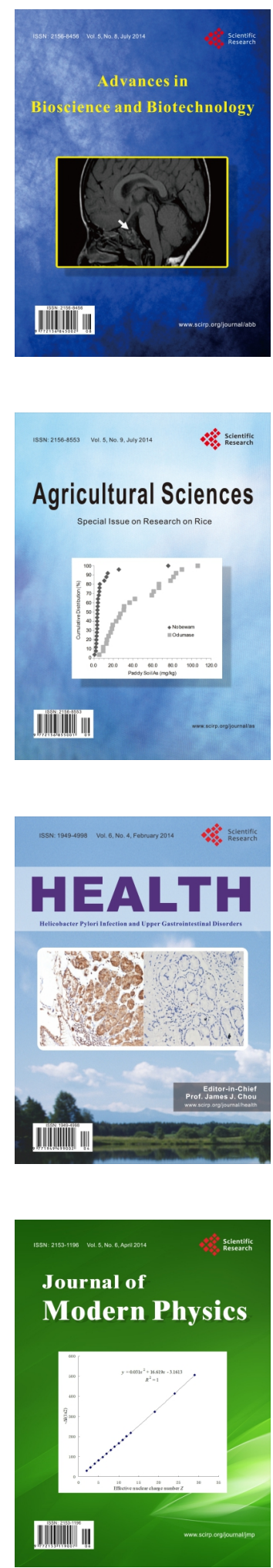
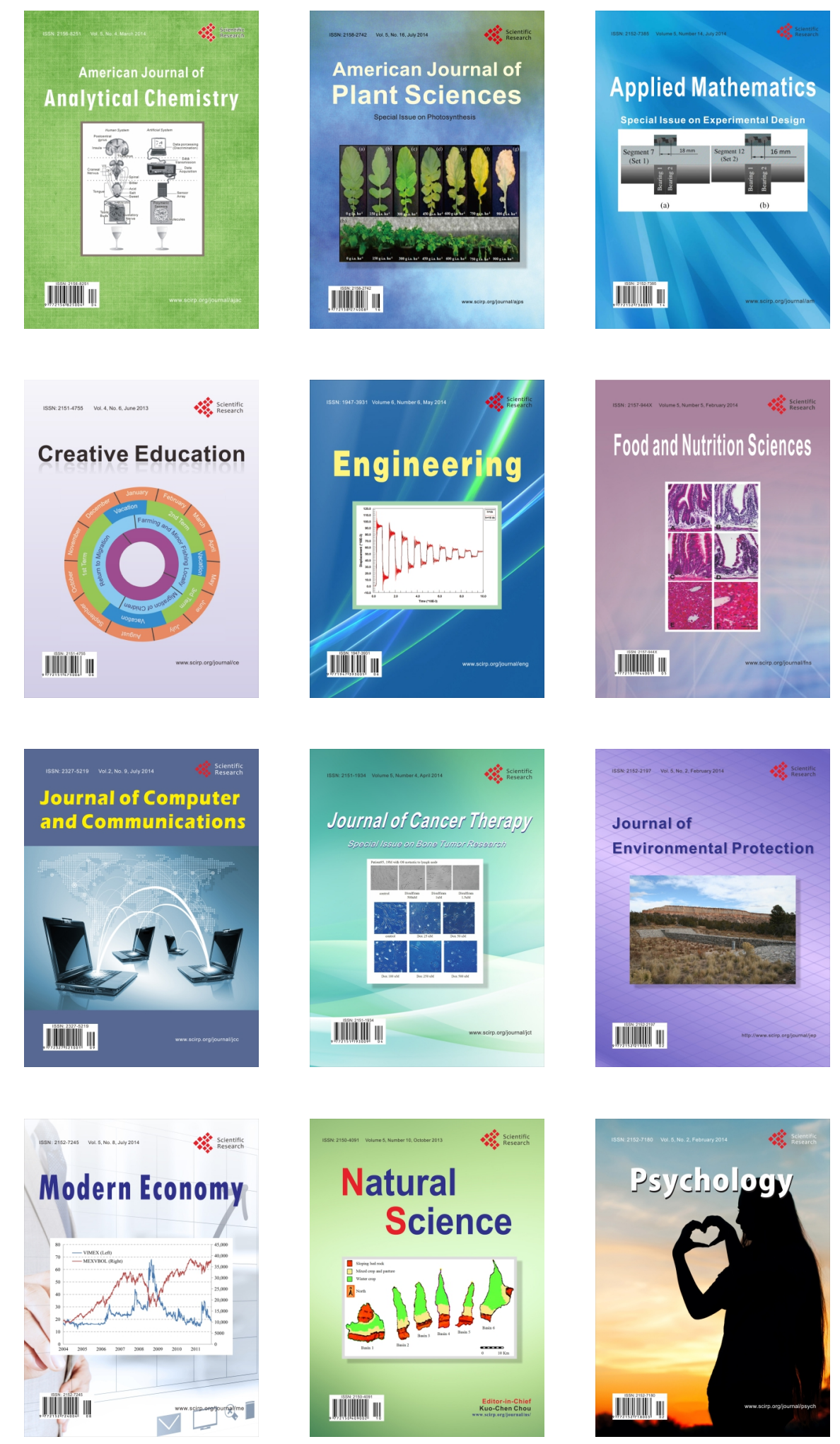